\title{
The Influence of Different Nanomaterials on the Growth of Fungi
}

\author{
Kholod K Salama ${ }^{1 *}$, Mona F Ali ${ }^{2}$ and Said M El-Sheikh ${ }^{3}$ \\ 1National museum of Egyptian civilization, Egypt \\ 2Faculty of Archaeology, Department of Conservation, Cairo university, Egypt \\ 3Nano-Structured Materials and Nanotechnology Division, Advanced Materials Department Central Metallurgical Research \& Development (CMRDI), \\ Egypt
}

Submission: July 28, 2018; Published: August 19, 2019

*Corresponding author: Kholod K Salama, National museum of Egyptian civilization, Cairo, Egypt

Keywords: Mauritius; Colonialism; Slavery; Indenture; Archaeology

\section{Introduction}

All paintings especially stored in unsuitable conditions suffered from microbial deterioration appeared as stains and discoloration (Figure 1). Bio deterioration is an undesirable process triggered by living organisms such as bacteria, fungi, algae and lichens which can affect cultural heritage and economically important materials. [1]. The physical factors which affect the growth of microorganisms are humidity, temperature and light. Some authors suggest bacteria as the first agents in the colonization of the mural paintings thus providing organic matter to the next colonizers fungi and lichens [2]. The metabolism of these microorganisms secretes oxalic acid $\left(\mathrm{H}_{2} \mathrm{C}_{2} \mathrm{O}_{4}\right)$ which can react with calcite $\mathrm{CaCO}_{3}$ present in the paintings giving rise to calcium oxalate $\left(\mathrm{CaC}_{2} \mathrm{O}_{4}\right)$ [3]. The growth of biological agents such as fungi is identified as a determinant factor in the degradation of the murals can cause vital deterioration factors such as discoloration of the mural surfaces, detachment of the fragments and biofilms formation. on other hand the bacilli generate energy from the oxidation of reduced sulphur compounds producing sulphuric acid as the end product [3] (Figure 1).

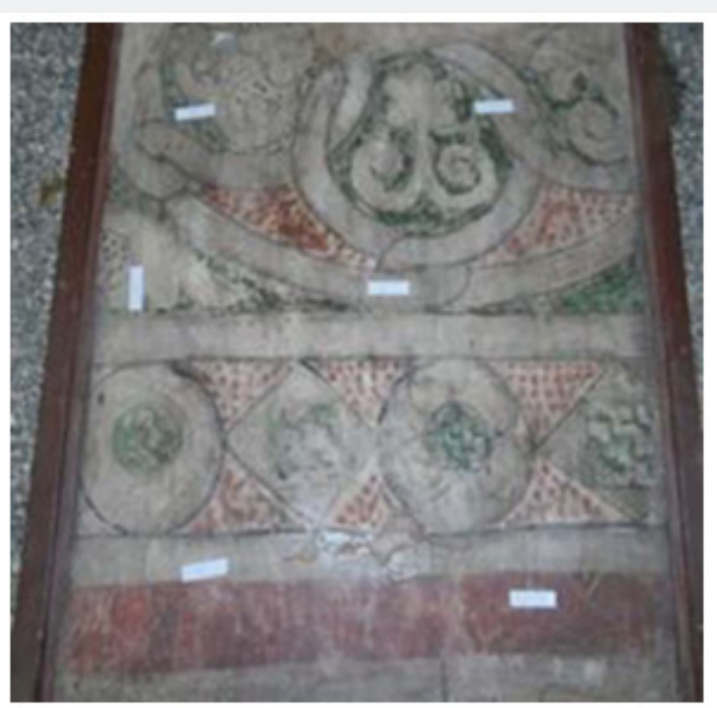

Figure 1: Detail of the painting with places of swabs. 


\section{Choosing different nano materials}

Currently in this paper nano materials which probably used for cleaning such as nano titanium dioxide, which is common in self-cleaning material, nano calcium hydroxide which consider the most successful consolidation nano materials, and nano silica, nano calcium carbonate which are probably used as filler in consolidation process. Those nano materials are already used for Cleaning and consolidation mural paintings.

\section{Materials and Methods}

\section{Sampling}

Samples were taken from the colored surface of the current mural painting under aseptic (free from contamination) conditions with sterile swabs.

\section{Isolation and characterization of microorganisms}

The samples recovered with sterile swabs were mechanically shaken for IH and inoculated under aseptic condition in different culture media specific to each microorganisms nutrient agar for bacteria, malt extract agar for filamentous fungi and yeast Extract peptone Dextrose agar for yeasts the cultures incubated at $30{ }^{\circ} \mathrm{C}$ for bacteria and fungi respectively the identification of the microbial isolates was performed based on the observation and macroscopic features such as texture and color of the colonies , hyphae morphology and observed with an optical microscope (OM) (Leica DM2500P) whose images were acquired in a camera Leica DFC290HD [4].

Current mural painting entails six fungi A. Fumigatus, Asergilluse Flavus, Asergilluse Niger, Asergilluse Terrus, Fuzarium and
Penicillum specie. The aim of this work is not only the isolation and characterization of the microbial organism affecting the mural painting of the Coptic museum storage backs to saint Jeremiah monastery $5^{\text {th }}$ century but also identify the role of nano material especially the nano materials will be used in cleaning and consolidation the undertaken mural painting which restored using nano materials [5].

\section{The Disk diffusion test}

Disc-diffusion test is a test of the material sensitivity for organisms. Currently nano materials are used to test the effectiveness on the diagnosis microorganisms. In this test, wafers containing nanomaterials are placed on an agar plate where fungi have been placed, and the plate is left to incubate. If the material stops the fungi from growing or kills them, there will be an area around the wafer where the fungi have not grown enough to be visible. Currently in this study the nano-materials effect the growth of fungi through measuring the diameter of clear zone or measuring the diameter of fungal colony then comparing the results before and after the test, even the diameter of the fungal colony shorter than the diameter of clear zone after adding the anti-material that is mean the material is effected the fungi.

\section{Nano- Materials Preparation (Antifungal)}

All nano materials purchased from nano tech com. LTD (nano silica, nano calcium carbonate, nano calcium hydroxide, and nano titanium dioxide) prepared in conc. $2 \%$ in ethanol (purity >99\%). Preparation of the mixed nanomaterial / system. The nanomaterial was sonicated in ultrasonic power 100 for 1 hour to make a homogenous suspension.

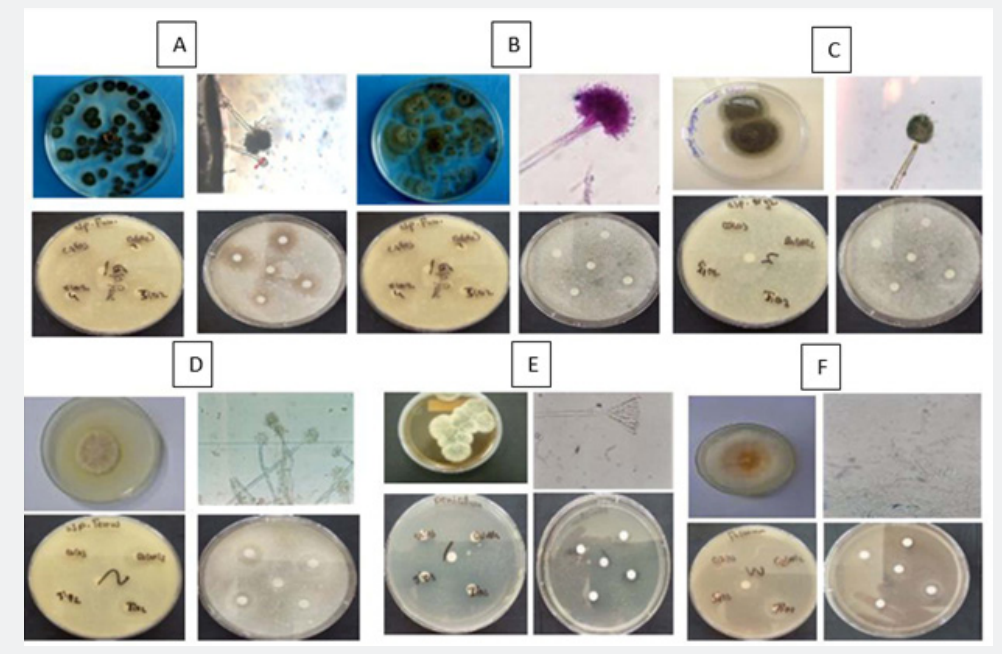

Figure 2:

A. The growth of A. Fumigatus in Pettry plate, The fungi under optical microscope, the disk diffusion test. B. The growth of Asergilluse Flavus in pettry plate, the fungi under optical microscope, the disk diffusion test.

C. The growth of Asergilluse Niger in pettry plate, the fungi under optical microscope, the disk diffusion test.

D. The growth of Aspergilluse terrus in Pettry plate, The fungi under optical microscope, the disk diffusion test.

E. The growth of Penicillium sp. in Pettry plate, The fungi under optical microscope, the disk diffusion test.

F. The growth of Fuzarium sp. in Pettry plate, The fungi under optical microscope, the disk diffusion test. 


\section{Nano-materials Effect}

Nano $\mathrm{SiO}_{2}$ : There are microorganisms colonizing on $\mathrm{Si}-\mathrm{O}$ so nano silica has affected some microorganisms as A.Fumigatus ( the diameter of clear zone) was $2 \mathrm{~cm}$ that assured the success of nano material in stop the growth of A.Fumigatus Figure 2 Nano $\mathrm{Ca}(\mathrm{OH})_{2}$ : assured it is success in consolidation and creating membrane helps in fumigation currently in this study with its circumstances the nano calcium hydroxide affected A. Fumigatus Fig.2 as the diameter of clear zone was $1.5 \mathrm{~cm}$ A. Fumigatus and according to terrus with the diameter of clear zone was $2 \mathrm{~cm}$ the nano mate-

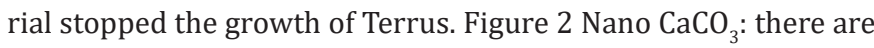
microorganisms colonizing $\mathrm{CO}_{3}$ as microorganisms attacking calcinid stone. so nano calcium carbonate hasn't affected any microorganisms. It is well known that the mixture of Titanium dioxide nanoparticles or zinc oxide nanoparticles with calcium hydroxide nanoparticles giving a big protection from the microorganisms specially the calcinied stones but currently in this study with its circumstances the nano calcium carbonate affected fungi as $A$. Fumigatus Figure 2 with the diameter of clear zone $2.5 \mathrm{~cm}$ and Niger Figure 2 with the diameter of clear zone $2.5 \mathrm{~cm}$ that means the nano calcium carbonate stopped the growth of them.

Nano $\mathrm{TiO}_{2}$ : Using Titanium dioxide $50 \%$ with calcium hydroxide in nature light or inside artificial light they affected the Penicillium and Niger [6]. Currently in this study the nano titanium dioxide affected all founded fungi as A. Fumigatus with the diameter of clear zone $1.9 \mathrm{~cm}$, Asergilluse Flavus with the diameter of clear zone $2 \mathrm{~cm}$, Asergilluse Niger with the diameter of clear zone $1.9 \mathrm{~cm}$, Asergilluse Terrus with the diameter of clear zone $1.3 \mathrm{~cm}$, Fuzarium with the diameter of clear zone $2 \mathrm{~cm}$ and Penicillum specie with the diameter of clear zone $1.5 \mathrm{~cm}$. Titanium dioxide is the most successful nano material in this study as it affects A.Fumigatus, Asergilluse Flavus , Asergilluse Niger, Asergilluse Terrus, Fuzarium and Penicillum specie. So nano titanium dioxide must be mixed with material as follows:

a. The calcium hydroxide which is popular used for consolidation must be mixed with titanium dioxide which proved its success in fumigation with all founded kind of fungi in the current mural painting, b. And according to use nano silica and calcium carbonate as filler must be also mixed with titanium dioxide which proved its success in fumigation.

\section{Conclusion}

This study indicates that the paintings of saint Jeremiah monastery have been colonized by fungi which seem to be responsible for the biofilm formation in the painting there seems to be a strong relationship between the most deteriorated areas with structural damage such as cracking and detachment of the paint layer and a higher microbial contamination. The fumigation using different nano materials especially the most successful material such as nano titanium dioxide which must be mixed with calcium hydroxide, or with nano fillers silica and nano calcium carbonate to prevent any growth of microorganisms.

\section{Acknowledgment}

The authors declare that There is no conflict of interest regarding the publication of this paper.

\section{References}

1. Rosada T, Candeias A, Caldeira AT (2006) Evaluation of mural paintings bio deterioration by oxalate formation, science and technology for the conservation of cultural heritage. Rogerio candelera, lazzari and cano (Eds.), Taylor and francis group, London, UK.

2. Shinkafi SA, Haruna I (2008) Microorganisms associated with deteriorated desurface painted concrete buildings with in Sokoto, Nigeria. International Journal of Current Microbiology and Applied Science 2(10): 314-324.

3. Katrin Ripka (2005) identification of microorganisms on stone and mural paintings using molecular methods, wien, Dezember pp. 1-100.

4. Carretti E, Dei L (2015) Cleaning I application, chapter 5, in nano science in conservation of work of arts. pp. 250.

5. Kholod K, Salama SM, El-Sheikh, Mona F Ali (2017) The conservation of an Egyptian Coptic fresco painting from saint Jeremiah monastery: the use of nanomaterials in cleaning and consolidation, Journal of Nano research.

6. La Russa MF, Ruffolo SA, Rovella N (2011) Multifunctional $\mathrm{TiO}_{2}$ coatings for cultural heritage. Progress in Organic Coatings 74: 186-191. 


\section{Your next submission with Juniper Publishers will reach you the below assets}

- Quality Editorial service

- Swift Peer Review

- Reprints availability

- E-prints Service

- Manuscript Podcast for convenient understanding

- Global attainment for your research

- Manuscript accessibility in different formats

( Pdf, E-pub, Full Text, Audio)

- Unceasing customer service

Track the below URL for one-step submission https://juniperpublishers.com/online-submission.php 